\title{
Kentsel Ekoturizm ve Isparta Kent Merkezinde Uygulanabilirliği
}

\author{
Beste İşcia ${ }^{*}$, Nurcan Pınarci ${ }^{b}$, Atila Gülc \\ a, bSüleyman Demirel Üniversitesi, Fen Bilimleri Enstitüsü, Isparta. \\ ‘Süleyman Demirel Üniversitesi, Mimarlık Fakültesi, Peyzaj Mimarlığı Bölümü, Isparta.

\section{$\ddot{O} z$} \\ Kent turizmi kapsamında "kent ekoturizmi", mevcut ekolojik değerleri koruma, \\ sürdürülebilirliğini sağlama, kente ve kent insanına hizmet verme bağlamında önem kazanmaya \\ başlamıştır. Kent ekoturizmi, yerel deneyimlerin artması, farklı kültürdeki insan topluluklarının \\ bir araya gelmesi, yöresel değerlerin önem kazanması, yöresel ve bölgesel ekonominin canlanması, \\ insanların yeni yerler keşfetmesi, doğal çevreye sahip çıkma bilincinin kazanılması gibi pek çok \\ sosyal, ekonomik, ekolojik ve çevresel yararlar sağlamaktadır. Kentin doğal ve kültürel değerleri \\ ekoturizm etkinlikleri için değerlendirilebilecek potansiyel kaynaklarıdır. Bu çalışmada, Isparta \\ kent içi ve yakın çevresindeki doğal ve kültürel değerlerin kent ekoturizm açısından potansiyeli \\ ortaya konulmuş ve geliştirilmesine yönelik öneriler sunulmuştur. Isparta kent ölçeğinde açık ve \\ yeşil alanlar, kültürel değerler, doğal ve ormanlık alanlar ve diğer değerler adı altında dört değger \\ grubu belirlenmiştir. Bu değerlere göre önerilen rotalar üzerinde ekoturizm etkinlikleri \\ ilişkilendirilmiştir. Isparta kent merkezinde ve yakın çevresinde yapılacak ekoturizm etkinlikleri \\ kapsamında, doğa yürüyüşü, dă̆ bisikletçiliği, bitki ve yaban hayatı gözlemciliği, doğa \\ fotoğrafçılı̆̆l, orientering, bitkilendirme çalışmaları, erozyon önleme çalışmaları, sokak hayvanları \\ bakım ve gelişimine yönelik çalışmalar, çöp toplama, gül toplama vb etkinlikler öngörülmüştür.
}

Anahtar Kelimeler: Kentsel ekoturizm, yeşil alanlar, eylem planı, Isparta kenti.

\section{Urban Ecotourism and Applicability in Isparta City}

\begin{abstract}
Urban ecotourism has come to the forefront in the context of protecting existing urban ecological values, ensuring its sustainability, providing service to urban people and to the city within the scope of urban tourism. Urban ecotourism provides many social, economic, ecological and environmental benefits such as the strengthening of local experiences, aggregation of human communities from different cultures, gaining importance of local values, revitalization of local and regional economies, discovering new places and raising awareness towards natural environment. Natural areas and cultural values of the city are potential resources that can be evaluated for ecotourism activities. In this study, natural and cultural assets of Isparta and its surroundings were examined and recommendations were made for the development of urban ecotourism. For this reason, value groups were identified in Isparta city scale; green areas, cultural values, natural and forest areas and other values. According to this values ecotourism activities in Isparta city center and its surroundings are trekking, mountain biking, plant and wildlife observation, nature photography, orienteering, planting studies, erosion prevention studies, street animal care and improvement activities, garbage collection, rose gathering and others.
\end{abstract}

Keywords: Urban ecotourism, green areas, action plan, Isparta. 


\section{GíRiş}

Ülkelerin ekonomik kalkınması açısından lokomotif görevi üstlenen turizm sektörü, nicelik ve nitelik açısından giderek değişmekte ve çeşitlenmektedir. 1990'l1 yıllardan itibaren kabul gören klasik turizm, çoğunlukla deniz (sea)+ güneş (sun)+ kum (sand) yani $3 \mathrm{~S}$ üçlemesiyle ilişkilendirilmiş ancak daha sonra bireysel ve özel ilgi turlarına doğru bir yönelme söz konusu olmuştur. Bu bağlamda eğitim, eğlence ve macera odaklı aktiviteler, doğal ve kültürel değerlerin korunması, yeni yerlerin keşfedilmesi ve ziyaretçi tatmininin artırılması kapsaminda her ülke kendi özelliklerine göre farklı turizm türlerini ön plana çıkarmaya çalışmaktadır. Bunun sonucu olarak yerli ve yabancı turistlerin değişen beklenti ve istekleri dikkate alınarak turizmin çeşitlendirilmesi gündeme gelmiştir.

Ülkemizde klasik turizme alternatif olabilecek turizm türleri; inanç turizmi, sağlık ve termal turizmi, kırsal turizm, kültür turizmi, kayak turizmi, yayla turizmi, av turizmi, golf turizmi, yat turizmi, hava sporları turizmi, kuş gözlemciliği turizmi, akarsu-rafting turizmi, sualtı dalış turizmi, dağcllık turizmi, botanik turizmi, kongre turizmi, mağara turizmi şeklinde sıralanmaktadır (Albayrak, 2013: 46).

Son yıllarda Türkiye'de "çevreye duyarlı turizm" anlayışı giderek önem kazanmaya başlamıştır. Bu amaçla ülkemizde turizmin çeşitlenmesine, turizmin tüm yıla ve tüm bölgelere yayılmasına, çevreye ve kültürel değerlere duyarlı turizm olgusunun yerleştirilmesine, yerel yönetimler ve halkın turizm ile ilgili kararlara katılmasını sağlayacak alternatif turizm projelerine ve uygulamalarına öncelik verilmektedir (Turizm Bakanlığ1, 1998).

1992 yılında gerçekleştirilen Çevre Zirvesi'nde doğal kaynakların korunması ve sürdürülebilir bir çevre için kararlar alınmıştır. Özellikle doğal ve kültürel kaynakları koruyarak ve onlara zarar vermeden turizm amaçlı yararlanma imkânlarının geliştirilmesi ve yöre insanlarının kültürlerini yok etmeden, turizm faaliyetlerinden yararlanmaları öngörülmüştür. Ekoturizm kavramı, ilk kez 1978 yılında Kenton Miller tarafından kullanılmış (Rahemtulla ve Wellstead 2001) ve özellikle 1990'lardan itibaren kavramsal çerçevesi, amacı ve uygulama sonuçları açısından tartışılan bir konu haline gelmiştir (Blamey, 1997).

Dünya Koruma Birliği'ne göre ekoturizm “Doğayı, kültürel değerler de dahil olmak üzere korumayı ve desteklemeyi amaçlayan, doğayı takdir etmek ve zevk almak için tahrip edilmemiş doğal alanlarda yapılan, ziyaretçi etkisinin minimum düzeyde olduğu, yöre insanının sosyo-ekonomik gelişmesine katkı sağlayan ve çevresel sorumluluk içeren bir seyahat olarak tanımlanmıştır (Wood, 2002).

Günümüze kadar yapılan tanımlar çerçevesinde ekoturizmin temel bileşenleri şu şekildedir (Gül ve Özaltın, 2007);

- Doğa temelli özellikle de doğanın yapısı ve işleyişi ile kültürel değerleri anlamaya yönelik bir çaba içerisinde olması ve bu çabayı korumaya dönüştürme eğiliminde olması,

- Biyolojik çeşitliliğin öncelikli korunması, 
- Yöre halkının aktif katılımının sağlanması,

- Yöreye sosyo-ekonomik yararlar sağlaması,

- Yerel halkın ve ilgili paydaşların çok yönlü sorumluluk üstlenmesi,

- Doğal ve kültürel kaynaklar üzerindeki olumsuz etkilerin en aza indirilmesi,

- Ekoturizm etkinliklerin küçük gruplarla yada bireysel olarak yapılması,

- Doğa ve çevre korumaya karşı farkındalığın ve bilincin artırılması,

- Doğal alanda yapı ve fiziksel tesisler minimum seviyede özellikle doğal çevreyle ve yerel mimariyle uyumlu olması,

- Doğaya karşı sorumlu, saygılı ve kabul edilebilir turizm etkinliği olmasıdır.

Ekoturizm, temel olarak doğal (biyolojik çeşitlilik, ilginç jeomorfolojik oluşumlar, ilginç iklim özellikleri ve görsel manzaralar vb) ve kültürel (tarihi ve arkeolojik kalıntı ve eserler, yöresel festivaller, folklor, yöresel ürün ve mimarisi, arazi kullanım desenleri vb.) kaynaklar olmak üzere iki çekim kaynağına sahiptir. Bu kaynakların ilginç ve ender rastlanılan türden olmaları ve özellikle keşfetme ve takdir değerlerinin yüksek olması kaynak değerlerinin çekiciliğini daha fazla artırabilecektir. Özellikle biyolojik çeşitlilik ile ilgili değerler ekoturizm açısından her zaman diğer değerlerden daha yüksek çekiciliğe ve öneme sahiptir (Gül ve Özaltın, 2007).

Günümüzde, doğa yürüyüşü (trekking), dağa tırmanma, kuş izleme, doğa fotoğrafçılığ1, yaban yaşam safarisi, kampçılık, rafting ve bitki gözlem ve inceleme gibi etkinlikler ekoturizm etkinlikleri olarak kabul görmektedir (Whelan, 1991; Gül ve Özaltın, 2007). Ancak doğada gerçekleştirilen her bir etkinliğin ekoturizm etkinlikleri olarak değerlendirildiği veya algılandığı da gözlenmektedir. Bu nedenle bir etkinliğin ekoturizm etkinliği olarak kabul edilebilmesi için bazı temel özelliklere sahip olmasını gerektirmektedir (Gül ve Özaltın, 2007). Ekoturizm etkinlikler;

- Doğal ve kültürel değerlere zarar vermemeli, aksine korunması ve gelişmesine katkıda bulunmalıdır,

- Kaynak değerlerine ve ekolojik bütünlüğe doğrudan ve çok yönlü katkıda bulunmalıdır,

- Doğa ve çevre etiğine uygun söylem ve eylemleri teşvik etmelidir,

- İnsana yönelik değil doğaya dönük olmalıdır,

- Dişsal değerlerden çok içsel değerler üzerinde yoğunlasmalıdır,

- Etkinlik sürecine yöre insanlarının aktif katılımı sağlanmalıdır,

- Etkinliklerde doğaya katkı, öğrenme ve takdir ölçüleri ile tatmin olma gibi temel hedefler gözetilmelidir.

Günümüzde ekoturizm uygulamalarına yönelik söylemlerin özüne uygun bir şekilde eyleme dönüştürülememesi doğal kaynakların olumsuz etkilenmesine neden olabilmektedir. Ortaya çıkan bu olumsuzlukları en aza indirgenmesi amacıyla bu etkinliklerin özellikle kentsel alanlarda ve çevresinde yapılmasının daha akılcı olduğu düşünülmektedir. Kent turizmi daha çok kentlerin yapılı çevresi ile ilgili olup mimari, anitsal, tarihsel ve kültürel mekânlar üzerinde genelde yoğunlaşmaktadır. Kentlerin sürdürülebilir ve çok yönlü gelişimlerinin sağlanması için turizm faaliyetlerinin çeşitlendirilmesine yönelik çabalar ve faaliyetler de her geçen gün artmaktadır. 
Bir kentin turistik destinasyonu başlica şehrin fiziksel özellikleri, kentsel toplum unsurları, yönetim (tedarik odaklı), pazarlama (ziyaretçi odaklı) olmak üzere dört boyuttan oluşmaktadır (Paskaleva-Shapira, 2007).

Avrupa sürdürülebilir kentsel turizm girişimi aşağıdaki şekilde belirtilmiştir (Paskaleva, 2001);

a) Kentsel turizm faaliyetlerinin mevcut altyapısı olan turistik alanlara ve kentsel yeşil alanlara erişebilmesini sağlamak,

b) Yerel toplumun kültürel ve sosyal yaşamının güçlendirilmesine katkıda bulunmak,

c) Yerel halkın ve ziyaretçilerin haklarını korumak,

d) Ekonomik canlılık (uzun vadede kalkınma ve nitelikli istihdam olanakları) sağlamak,

e) Ulaşımı uygun düzenlemek suretiyle ekolojik zararları en aza indirgemek,

f) Sürdürülemez tüketim kalıplarını ortadan kaldırmak.

Olumsuz ekolojik etkilerin en aza indirilmesi, yerel halk ve ziyaretçilerin bu olumsuzluklardan etkilenmemesi için turizmin sürdürülebilir gelişimini sağlamak amacıyla kentsel turizmin teşvik edilmesi gerekmektedir (Paskaleva, 2001).

Kentsel turizmde daha çok ekonomik ve sosyal gelişmeye yönelik kültürel değerler ön planda olmaktadır. Ancak kentlerin sosyal-ekonomik ve ekolojik gelişmenin sağlanabilmesi için ekoturizm önemli bir bileşen olarak karşımıza çıkmaktadır (Wright, Hall ve Lew, 1998).

Bu bağlamda "Kent ekoturizmi" giderek önem kazanmakta ve içeriği net olarak tanımlanmadığı için bu kavramın geliştirilmesinin gerekliliği vurgulanmaktadır (Wu ve Wang, 2007; Wu vd. 2010). Bu nedenle, kent ekoturizm kavramının içeriğini tartışılması ve bilimsel bir yaklaşımın geliştirilmesi gerekmektedir.

$\mathrm{Bu}$ çalışmanın amac1, kent ekoturizminin geliştirilmesine vurgu yapmak, önemli doğa ve kültür turizmi potansiyeline sahip Isparta kentinin ve yakın çevresindeki doğal ve kültürel değerlerin ve alanların kent ekoturizmi açısından potansiyelini ortaya koymak ve kent ekoturizminin geliştirilmesine yönelik öneriler sunmaktır.

\section{KENT EKOTURIZMI}

Kent ekoturizmi, ilk olarak Blackstone Corporation (1996) tarafından önerilmiş ve kentsel alanlara yapılan sürdürülebilir seyahatler edilmesi olarak kabul edilmiştir. 2004 yılında Kanada'da yapilan Kentsel Ekoturizm "Urban Ecotourism Conference" adlı konferansta, Kent Ekoturizmi; "Şehirlere yapılan bir doğa seyahati olup şehirlerin korunmasına yönelik faaliyetleri içermektedir. Kentsel alanlarda yaşam kalitesini artırılması, yeni iş imkânlarının yaratılması, biyolojik ve sosyal çeşitliliğin korunması amaçlanmaktadır".

Kentsel turizm, aslında dünyanın en popüler turizm türlerinden biri olarak kabul edilmekte ve bir şehrin gelişiminin ve tanıtımının ayrılmaz bir parçası olarak değerlendirilmektedir. Doğal alanlara seyahat eden kitlenin çoğunlukla kent insanı 
olduğu düşünülürse ekoturizm faaliyetlerine katılan ekoturistlerin de genellikle kentli insanlar oldukları kabul edilebilir. Doğaya yönelik olarak yapılan seyahatlerin aslında kent içinde doğal veya yeşil alanların yetersiz ve sınırlı olması ve kent insanı için tatmin edici bir ortamın olmamasından kaynaklandığı öngörülmektedir.

Kent ekoturizmi, aslında kent doğal ekosistemine saygı duyan bir turizm anlayışı olup kentin doğal ve kültürel kaynak değerlerinin keşfedilmesi ve gezilmesi olarak algılanmaktadır. Ayrıca, ilgili paydaşların kent ortamında ki doğal ve kültürel mirasın korunması ve yenilenmesine yönelik odaklanmayı da içermektedir. Kent ekoturizmin 4 temel amacı vardır (Urban Ecotourism Declaration (UED), 2006):

- Doğal ve kültürel mirası (doğal peyzaj, biyoçeşitlilik, yerel kültür) korumak ve yenilemek,

- Yerel yararları maksimize etmek, yerel halkın misafirlerin barınma ihtiyaçlarını karşılamasını ve rehberlik etmesini sağlamak,

- Çevresel konular, tarihi miras değerleri ve sürdürülebilirlik konularında kent insanının ve ziyaretçilerin farkındalıklarını artırmak ve bilinçlendirmek,

- Ekolojik ayak izlerini azaltmak şeklinde ifade edilmiştir.

Yukarıda belirtilen tanımlardan özet olarak, kentsel ekoturizmi; kentin ekolojik ve kültürel miras değerlerinin sürekliliğini koruyarak, kente ve kent insanına ekolojik ve ekonomik gelişme imkanı sağlayan, insanların farkındalık ve bilinç düzeyini artıran kente uygun ekoturizm faaliyetleri ve politikası olarak tanımlamak mümkündür (Şekil 1).

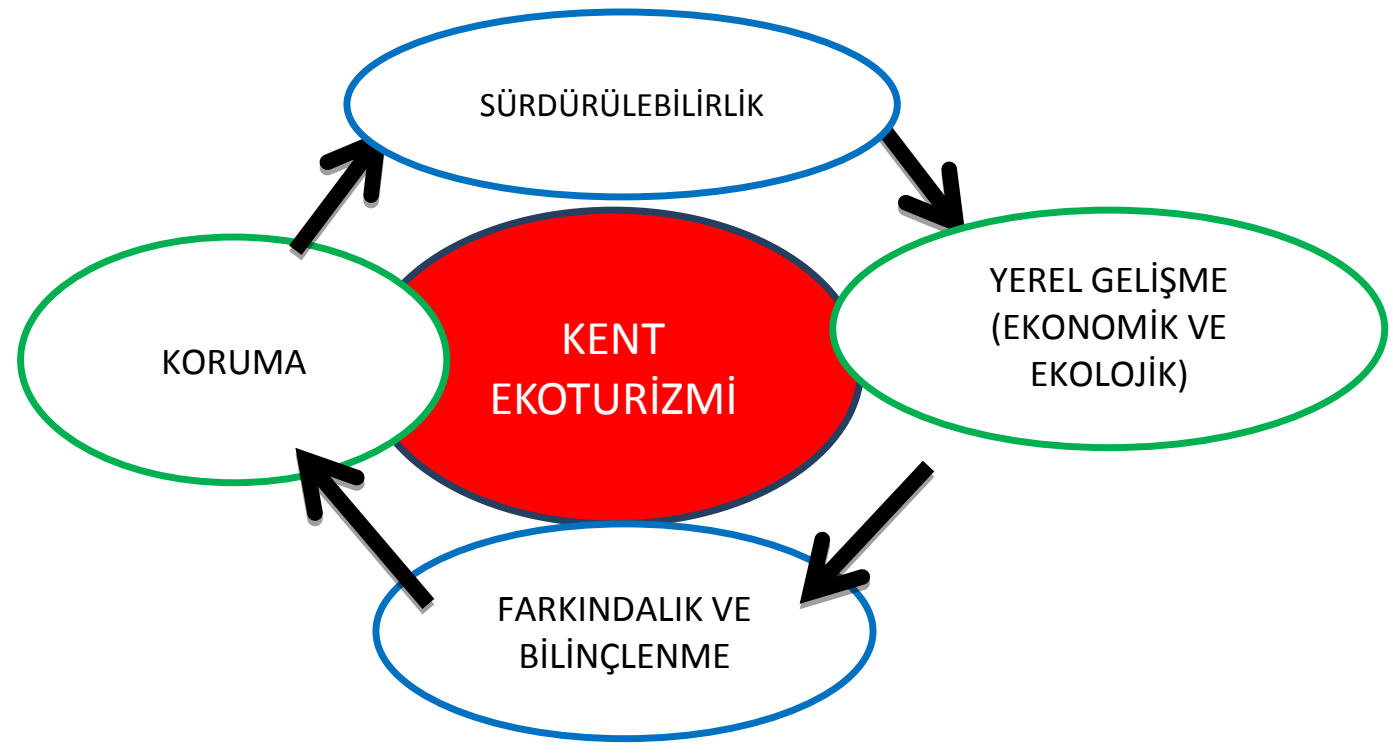

Şekil 1. Kent ekoturizminin temel bileşenleri

Wu vd. (2010)' ye göre kent ekoturizmin 3 temel yararı bulunmaktadır. Bunlar sosyal, ekonomik ve çevresel yararlardır (Şekil 2).

Sosyal Yararlar: Kentsel alanda yaşayan toplulukların mekan algıları, fiziksel özellikler hakkında bilgi elde etmeleri ve toplu öğrenme faaliyetleri nedeniyle yerel 
deneyimler artar. Böylece kent insanında ve ziyaretçilerde yöre ile gurur duyma ve sahip olma duygusu gelişir. Kentsel yaşamda farklı kültürlerin bir araya gelmesi nedeniyle farklı toplulukların birbirleriyle olan ilişkisini vurgulamak suretiyle, yerel kültürün, yerel ürünlerin ve rekreasyon faaliyetlerinin teşvik edilmesini sağlar.

Ekonomik Yararlar: Yöreye ait mal ve hizmetlerin tüketimini teşvik ederek yerel ekonomiyi canlandırır. Yöresel ekonomide para dolaşımına yol açarak ekonomik fayda sağlar, böylece yerel esnekliği güçlendirir.

Çevresel Yararlar: Aktif ulaşımı teşvik ederek (bisiklet sürmek, yürümek) kentsel yerlerin keşfedilmesini sağlar ve enerji kullanımını azaltır. Kentsel ve doğal çevre arasındaki bağlantıları vurgulayarak, doğal ve kültürel mirasın korunması, canlandırılması ve korumacılık eylemlerinin hayata geçirilmesi ile çevresel farkındalığı teşvik eder.

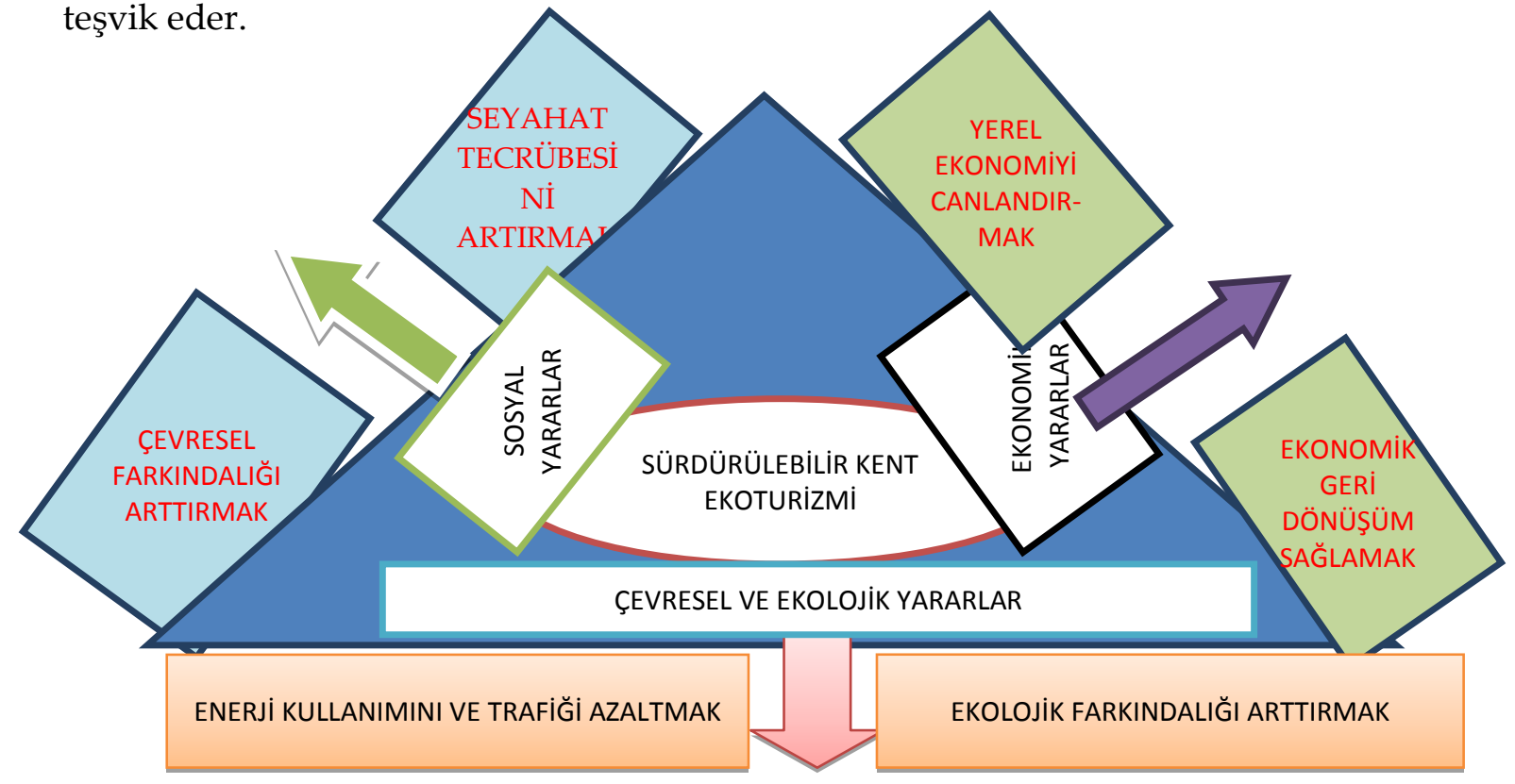

Şekil 2. Kent Ekoturizmin Yararları (Wu ve diğ. 2010)

Sürdürülebilir kentsel kalkınma ve turizm faaliyetleri arasında yer alan özel bir alan olarak kentsel ekoturizm, klasik ekoturizm amaçlarının aksine, endüstrileşme, alt yapı, trafik ya da diğer insan faaliyetleri sonucu bozulmuş kentsel alanları yenilemek için bir araçtır. Kentsel ekoturizm, turistik şehirleri korumak için ekolojik unsurları geliştirerek şehri desteklemektedir. Ekoturizm, ekolojik sürdürülebilirlik standartları dikkate alınarak girişimcilerin ve yerel toplumun ekonomik ve sosyal yarar elde etmeleri için yeni bir yoldur. Aslında, turistler turistik çekiciliği olan şehirleri keşfetmek için yeni yollar aramaktadırlar. Bu nedenle, kentsel ekoturizm turist beklentilerini karşılamak ve sürdürülebilir kalkınmayı sağlamak için önemli bir anahtar görevi üstlenecektir.

Doğal alanlarda yapılan ekoturizm faaliyetleri sonucunda ihtiyaç duyulan alt ve üst yapılarının geliştirilmesi sonucu doğal kaynaklar tahrip edilebilmekte ve zarar 
verilebilmektedir. Mc Laren (2003)'e göre kentsel ekoturizmin doğal alanlara göre daha avantajlı olduğu ifade etmektedir.

- Kentsel ortamda mevcut imkanlar kullanıldığ1 için çevreye daha az müdahale edilmektedir. Örneğin kentsel ekoturistler etkinlikleri halihazırdaki mevcut altyapıları ve taşıma araçlarını kullanarak gerçekleştirmektedir. Bu nedenle, bu alanlarda çevresel değeri bozan altyapıların yaratılmasına ihtiyaç duyulmamaktadır (Higham ve Luck, 2002).

- Doğal kaynakların korunması ve rehabilite edilmesi ile kentsel doğal alanların sürdürülebilirliği sağlanabilir ve şehrin ekosistemine ve yaşam kalitesine katkılar sunulabilir. Nitekim Avustralya ve Yeni Zelanda'da kent sinırları içinde bulunan doğal alanlardaki ekoturizm girişimleri, ziyaretçilerin "eşsiz ekoturizm" deneyimi elde etmesine imkan sağlarken aynı zamanda bu alanların korunabileceği ve şehirdeki yaşam kalitesini artırabileceği kanıtlanmıştır. Ayrıca, nesli tükenmekte olan türler için yaşam alanları yaratılması ve bölgede yok olma tehlikesi ile karşı karşıya olan türlerin üremelerinin desteklenmesi mümkün olabilmektedir (Higham ve Luck, 2002).

- Yerel halkın ve ziyaretçilerin farkındalık ve bilinç düzeyinin artırılması sağlanabilir. Kentsel alanlar, "koruma ve koruma konularına yönelik tutum ve davranışları" değiştirmek için daha geniş bir hedef kitleye sahip olduğundan sürdürülebilirliği daha büyük ölçekte teşvik etmek mümkündür (Dodds ve Joppe, 2001; Higham ve Luck, 2002; Okech, 2009). Farkındalık ve bilinçlenme süreci ile doğa ile uyumlu kent kültürünün gelişmesine katkı sağlanabilir.

- Finansal uygulanabilirlik, Kent ekoturizminin, daha geniş bir kitleyi cezbetmesi ve etkilemesi sonucu daha fazla gelir yaratılabilir. Kent ekoturizmi genellikle diğer turizm türlerine göre daha az mevsimseldir. Ekoturizm etkinlikleri her mevsim yapılabilir (Higham ve Luck, 2002).

\section{MATERYAL ve YÖNTEM}

Isparta kent içi ve yakın çevresinde bulunan ve ekoturizm açısından değerlendirilebilecek doğal ve kültürel değerler çeşitli ikincil kaynaklar kullanılarak ve yazarların gözlemleri ile belirlenmiştir. $\mathrm{Bu}$ değerler kullanılarak Isparta kent ekoturizmine yönelik rotalar belirlenmiş ve rota üzerinde yapılabilecek bazı etkinlikler öngörülmüştür. Isparta kent ekoturizmi açısından kullanılabilecek potansiyel değerler, 4 grupta toplanmıştır. Bunlar; kentsel açık ve yeşil alanlar, kentsel kültürel (tarihi, sanatsal, geleneksel vb) değerler, kent içi ve yakın çevresinde bulunan doğal ve ormanlık alanlar ve diğer değerler şeklinde gruplandırılmıştır. Bu amaçla Google Earth 2018 Digital Globe Uydu görüntüsü ile Isparta kenti ve yakın çevresi için altlık oluşturulmuştur.

Bu altlık yardımı ile Isparta kentinin ekoturizm açısından kullanılabilecek doğal ve kültürel değerler noktasal veya alansal belirlenerek işaretlenmiş, mevcut ulaşım yolları (araç ve yaya yolları ve patikalar) dikkate alınarak rotalar oluşturulmuştur. 


\subsection{Isparta Kentinin Sahip Olduğu Doğal ve Kültürel Değerler}

Isparta kent çevresinde ekoturizm amaçlı değerlendirilebilecek potansiyel kaynaklar şunlardır;

Kentsel açık ve yeșil alanlar: Kent parkları (Ayazmana Tarihi Mesirelik Parkı, Gökçay Parkı), çok sayıda mahalle parkı, Milas mesireliği, Çay boyu yeşil kuşak, Süleyman Demirel botanik bahçesi, SDU yerleşkesi, kent ormanları, tarım alanları ve gül bahçeleri, elma ve kiraz bahçeleri vb yeşil alanlar kent ekoturizmi açısından değerlendirilebilecek açık ve yeşil alanlardır (Şekil 3).

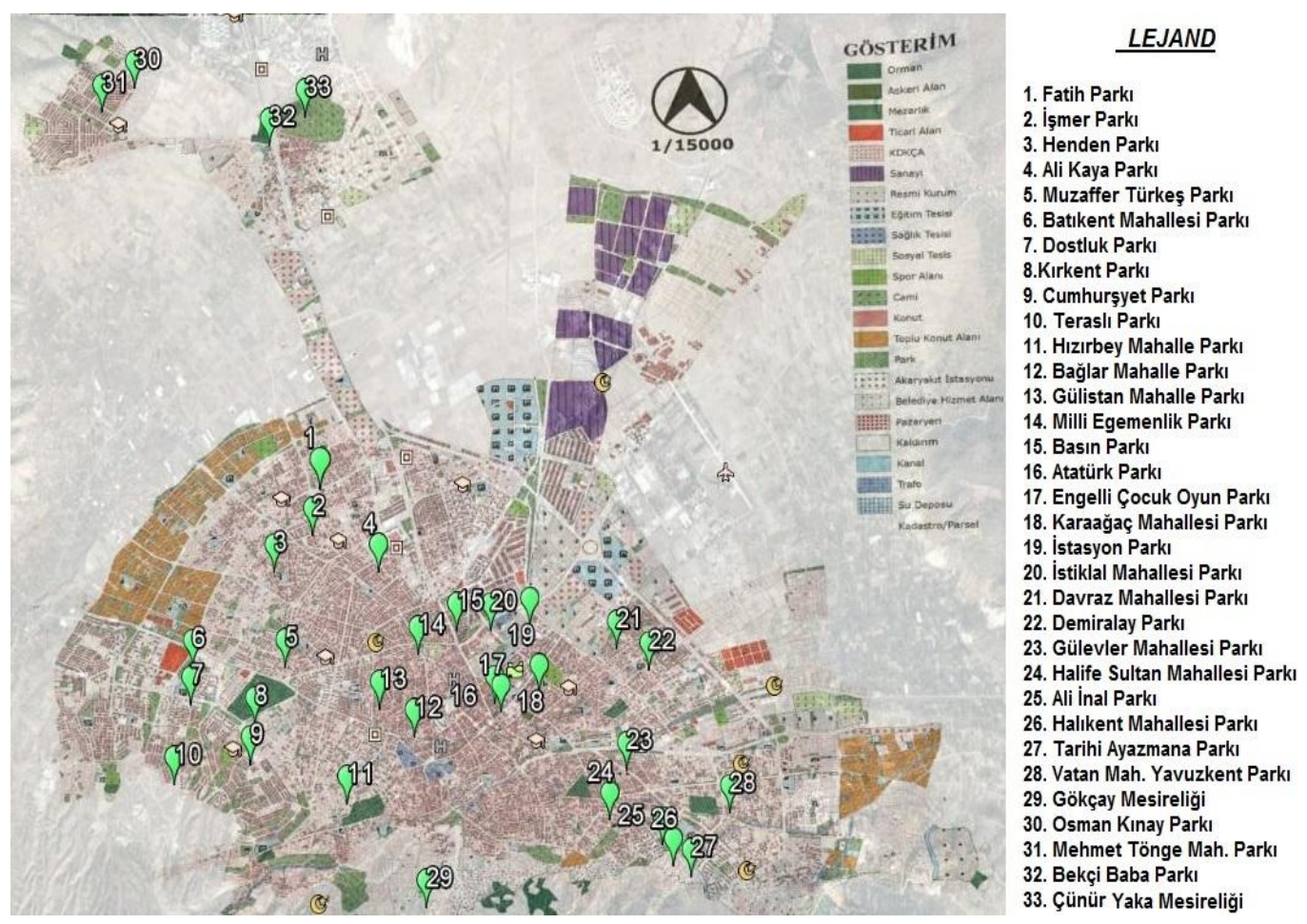

Şekil 3. Isparta Açık ve Yeşil Alanlar

Kentsel kültürel (tarihi, sanatsal, geleneksel vb) kaynaklar: Isparta kenti tescilli anıtsal mimari yapılar; Valilik Binası, Bedesten Çarşısı, Dalboyunoğlu Hamamı, Bey Hamamı, Mimar Sinan Camii, Ulu Camii, İplikçi Camii: Kavaklı Cami, Gazi İlkokulu, Cumhuriyet İlkokuludur. Bu alanlar, Koruma Amaçlı İmar Planı kapsamında tescil edilen alanlardır. Bu alanlar ekoturizm kapsamında değerlendirilebilecek değerlerdir. Bölge Atatürk Parkı, Bedesten Çarşısı, Valilik, Bey Hamamı ve Ulu Cami'nin de içinde yer aldığı bölgedir. Bölge Mimar Sinan Cami ve Üzüm Pazarı olarak tarif edilen Atatürk Bulvarı ile Mimar Sinan Caddesi'nin kesiştiği bölgede yer alır. Bölge Hasan Fehmi ile Fevzi Paşa Caddesi arasında yer alan, 1306 (Damgacı Sokak), 1311, 1313, 1410, 1411, 1412, 1413 ve 1414 sokakları kapsayan, Gazi İlkokulu, Cumhuriyet İlkokulu ve İplikçi Cami'nin bulunduğu bölgedir.

Bu kültürel değerlerin yanısıra bölgede Isparta Müzesi, Isparta Etnografya Halı ve Kilim Müzesi, GÜLBİRLİK Gül ve Kozmetik Ürünleri Üretim Merkezi ve Gül Müzesi türbeler, kilise, Isparta Evleri, çeşmeler vb de mevcuttur (Şekil 4). 

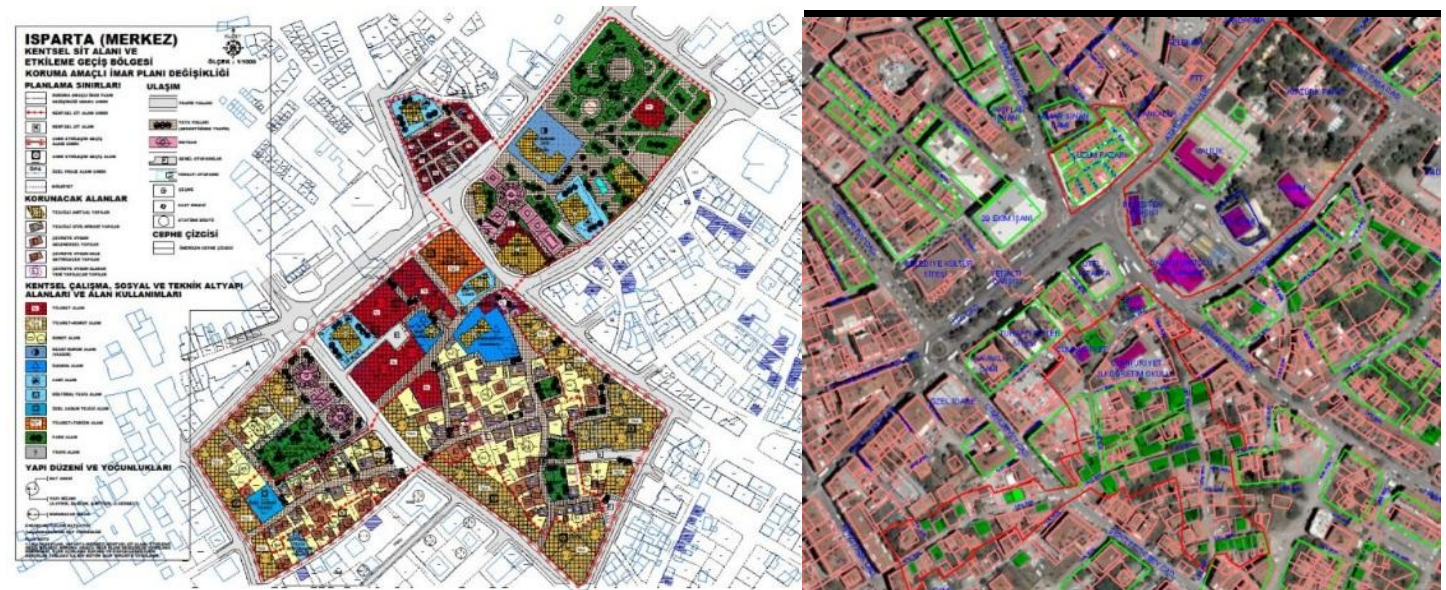

Şekil 4. Isparta Kenti Tescilli Kültürel Kaynaklar

Kent içi ve yakın çevresinde bulunan doğal ve ormanlık alanlar: Bu alanlar arasında, Gölcük Gölü Tabiat Parkı, Anıt Ağaçlar (tescilli yaşlı kestane ve çınar ağaçları), Kermes Meşesi Tabiat Koruma Alanı, Davraz Kayak Merkezi, faaliyetleri sona ermiş olan mermer ve taş ocakları vb sayılabilir (Şekil 4).

Ekoturizm amaçlı kullanılabilecek diğer simge veya değerler: Bunlar arasında Isparta kenti ile bütünleşen özel obje/ürün ve alanlar sayılabilir. Örneğin Isparta hayvan barınağı, Isparta gülü, Kasnak Meşesi, Isparta Halısı vb.

\section{BULGULAR ve TARTIŞMA}

\subsection{Isparta Kent Ekoturizmi Kapsamında Yapılabilecek Etkinlikler}

Genelde doğal alanlarda gerçekleştirilen ekoturizm faaliyetleri doğaya yarardan çok zarar vermektedir. Bu bağlamda ekoturizm faaliyetlerini kent içinde ve çevresinde öngörülmek suretiyle kentsel ölçekte katma değer sağlaması hedeflenmiştir. $\mathrm{Bu}$ nedenle Isparta kent ölçeğinde mevcut kaynak değerlerinin ekoturizm amaçlı değerlendirilmesi ve kent ekoturizminin yaygınlaştırılması büyük önem taşımaktadır.

Isparta kent merkezi ve yakın çevresinde yapılabilecek etkinlikler şunlardır; yürüyüş (trekking), bisikletle gezi, kuş gözlemciliği, bitki gözlemciliği, fotoğraf çekme, ağaçlandırma veya bitkilendirme faaliyetleri (fidan dikme, tohum ekme), erozyon önleme çalışmaları (eğimli yerlerde taş duvarlar örülmesi, teraslama), sokak hayvanlarını koruma faaliyetleri, gül bahçelerinde gül toplama ve bakım faaliyetleri, parklarda yabani ot temizliği, kültürel eserlerin ziyareti ve orienteering (hedef bulma) vb. Bu etkinlikler tek tek yapılabileceği gibi bu etkinlikleri birbirleriyle birleştirilerek rotalar halinde organize etmek te mümkündür.

\subsection{Isparta Kent Ekoturizmine Yönelik Önerilen Rotalar}

Isparta kent merkezinde kent ekoturizmine yönelik 4 farklı rota oluşturulmuş ve bazı ekoturizm etkinlikleri önerilmiştir. Bu rotalar belirlenirken insanların doğayla iç içe olmasına olanak sağlamak, farklı mekanları keşfetmek ve hissetmek, farklı etkinlikleri gerçekleştirebilmek amacıyla kısa ve uzun mesafeli olabilecek şekilde güzergâhlar tercih edilmiştir. Bu rotalarda bisiklet ya da yaya olarak yürümek suretiyle 
rota boyunca farklı etkinlikleri yapma imkanı (bitki gözleme, yaban hayvanları veya kuş gözleme, fotoğraf çekme, çadır kamp yapma, fidan dikme veya tohum ekme, gül toplama vb.) olabilecektir.

1. Nolu Rota: SDÜ Botanik Bahçesi ve Herbaryum Araştırma ve Uygulama Merkezi-Mermer Rehabilitasyon Alanı-Çünür Yaka Tepesi-Davraz Kayak MerkeziDarıdere Barajı-Ayazmana Mesireliği-Gökçay Mesire Alanı-Gölcük Gölü-Milas Mesireliği-Isparta Valiliği rotası sarı renkte gösterilmiştir ( Şekil 5).

$\mathrm{Bu}$ rota üzerinde bulunan botanik bahçesinde bitkilerle ilgili gözlem ve incelemeler, bitkilendirme etkinlikleri, üretimi sona ermiş olan mermer ocağında ve Çünür Yaka Tepesi'nde rehabilitasyon ve bitkilendirme etkinlikleri, manzara seyretme ve fotoğraf çekme vb etkinlikler, Darıdere Barajı'nda foto safari ve doğa gözlemi, Ayazmana parkında doğa gözlemi, foto safari, orienteering, yaban hayatı gözlemleme vb etkinlikler, Gölcük Gölü ve Davraz Kayak Merkezi noktasında dinlenme, doğa gözlemi, kamp ve orienteering gibi etkinlikler yapılabilecektir (Şekil 5).

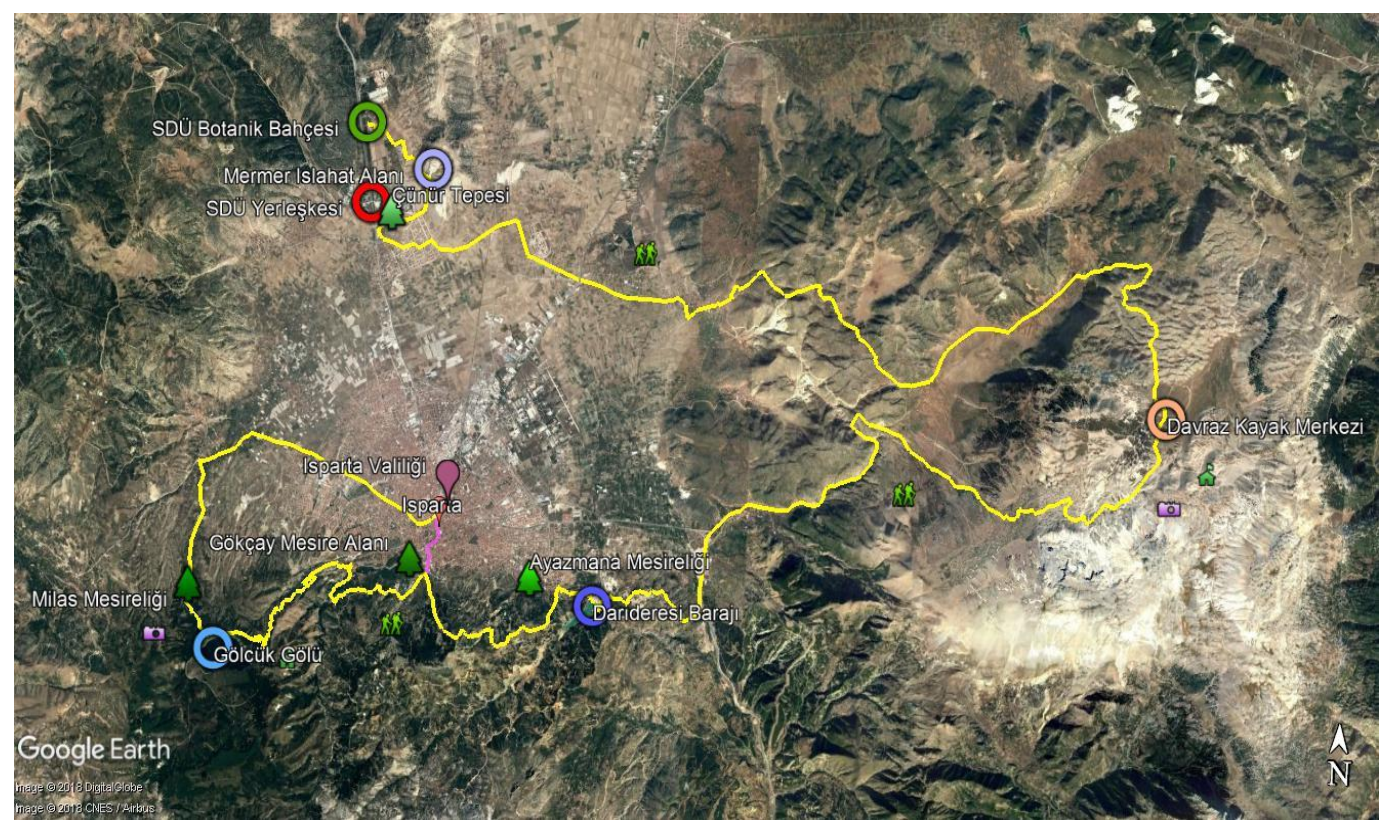

Şekil 5. Isparta Kenti 1. Nolu Ekoturizm Rotası

2. Nolu Rota: Toplam 30 kilometre uzunluğunda olan bu rota üzerinde mermer rehabilitasyon alanı-Isparta Hayvan Barınağ1-Gül Toplama Alanı-Milas MesireliğiGölcük Gölü-Gökçay Mesire Alanı ve Isparta Valiliği yer almakta ve turuncu renkte gösterilmiştir (Şekil 6).

Turuncu renk ile gösterilen bu rotada, üretim faaliyetleri sona ermiş olan mermer ocaklarında rehabilite çalışmaları veya fidan dikimi etkinlikleri, manzara seyretme, dinlenme ve fotoğraf çekme, Isparta hayvan barınağındaki sokak köpeklerine bakım ve besleme etkinlikleri, gül tarlalarında gül toplama ve dikim etkinlikleri, Milas Mesireliği, Gölcük Tabiat Parkı, Gökçay Parkında dinlenme, doğa gözlemi, orienteering ve kamp etkinlikleri, kent merkezinde müze ziyareti, tarihi mekânların ziyaret edilmesi gibi etkinlikler gerçekleştirilebilir (Şekil 6). 


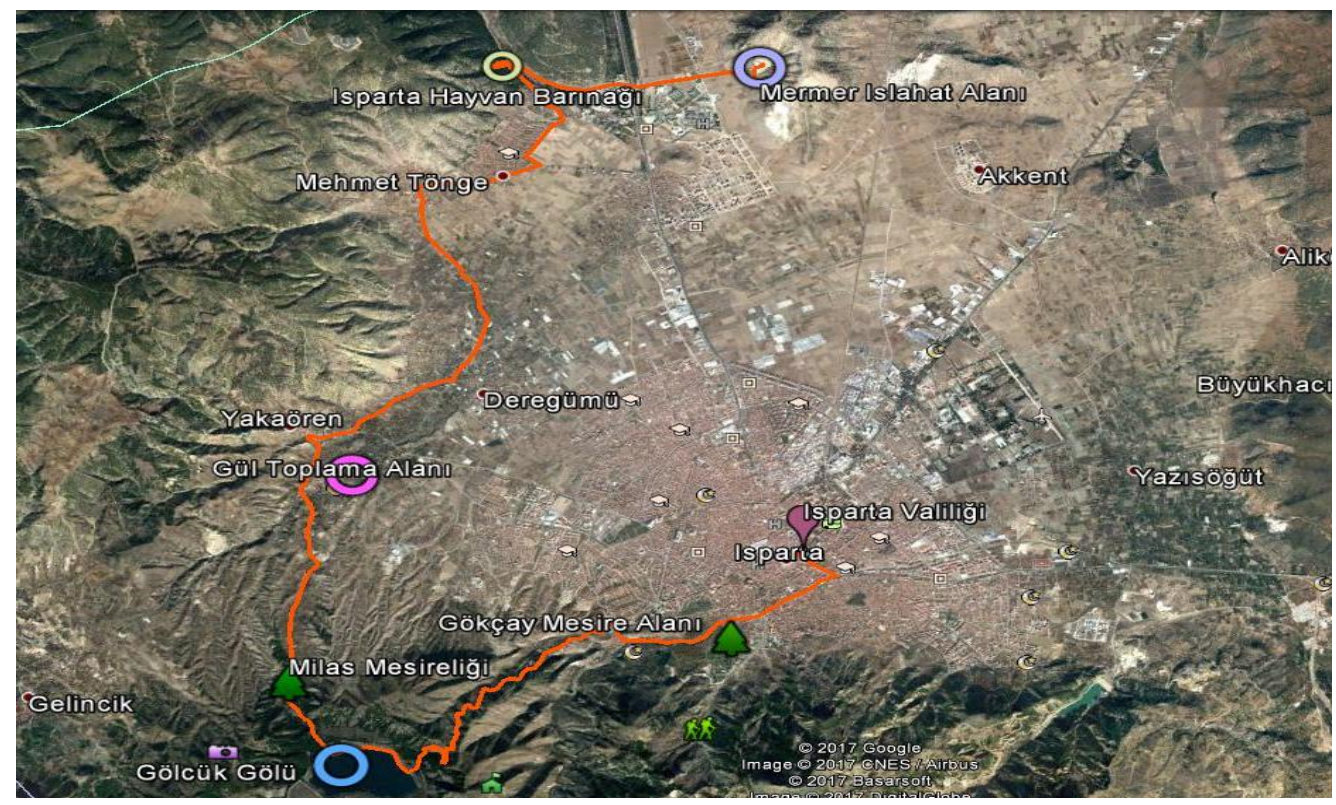

Şekil 6. Isparta Kenti 2. Nolu Ekoturizm Rotası

3. Nolu Rota: Bu rota, SDÜ Yerleşkesi-Gülbirlik Müzesi-Isparta Kent MüzesiCumhuriyet Hamamı-Isparta Etnografya Halı ve Kilim Müzesi-Tarihi Gökçay Mesireliği-Ayapana Kilisesi-Hızır Baba Türbesi-Firdevs Bey Bedesteni ve Cami-Eski Üzüm Çarşısı-Isparta Valiliğini içermektedir (Şekil 7).

Mor renk ile gösterilen bu rotada, kentin kültürel karakteri ve kimliği gözlemlenebilir. Bu kapsamda eski Isparta evlerini ziyaret etme, müze, tarihi cami ve hamamlar, Üzüm çarşısı ve kiliseleri inceleme, fotoğraf çekme ve bu alanların restorasyon ve bakımına katkıda bulunma gibi çok sayıda kültürel faaliyet yapılabilmesi mümkündür (Şekil 7).

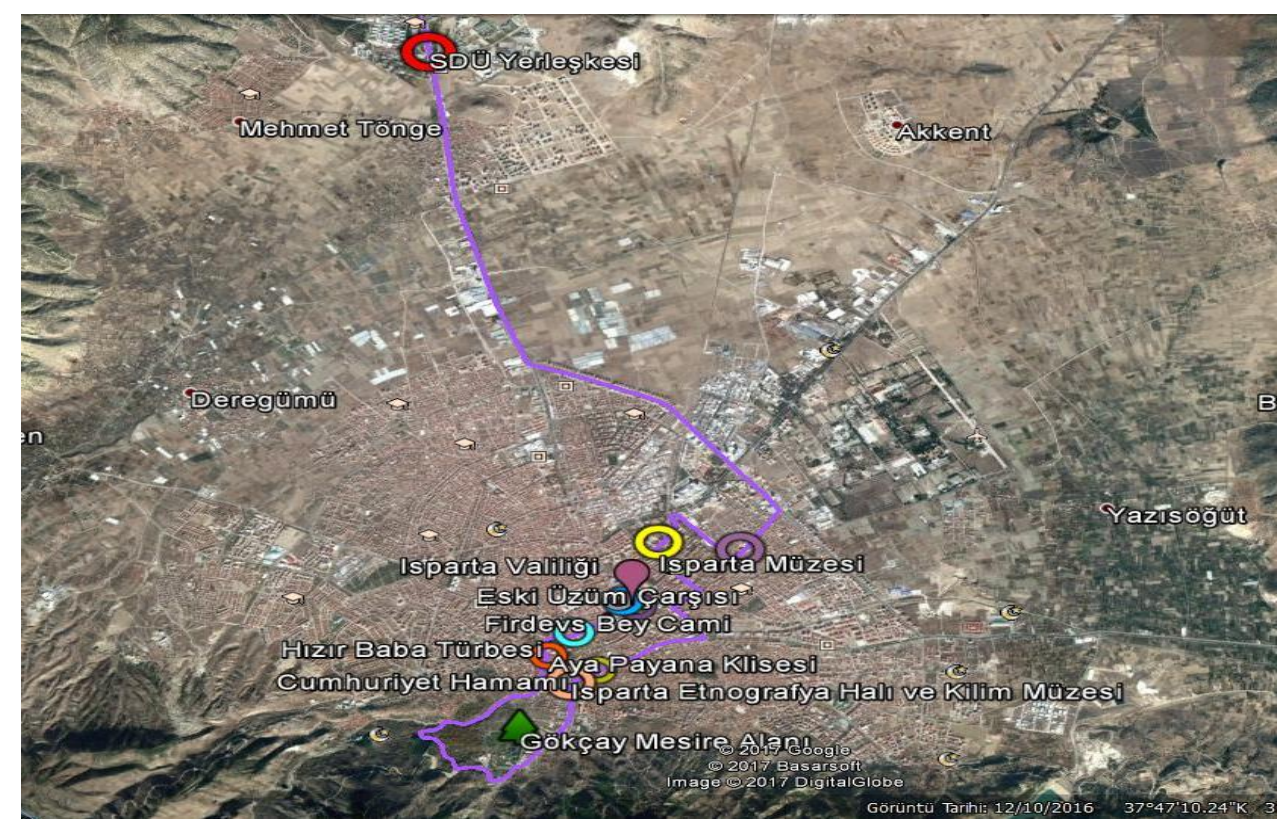

Şekil 7. Isparta Kenti 3. Nolu Ekoturizm Rotası 
4. Nolu Rota: İsteğe göre değişebilen 2 ayrı rota öngörülmüştür. Bu kapsamda önerilen yeşil renkli rotada; SDÜ Botanik Bahçesi ve Herbaryum Araştırma ve Uygulama Merkezi-SDÜ Yerleşkesi-Çünür Tepesi-Ayazmana Mesireliği-Gökçay Mesire Alanı-Gölcük Gölü-Milas Mesireliği-Isparta Valiliği bulunmaktadır (Şekil 8). Pembe renk ile gösterilen diğer rotada ise Isparta Valiliği 'ne 24 kilometre Davraz Kayak Merkezi 'ne bağlayan geçiş noktası ile Gökçay mesireliğinden Isparta Valiliği 'ne ulaşım sağlanabilen 2 kilometrelik yol ile doğa gözlemi, foto safari, orienteering, kamp, çöp toplama, fidan dikimi gibi çeşitli etkinlikler öngörülmüştür (Şekil 8).

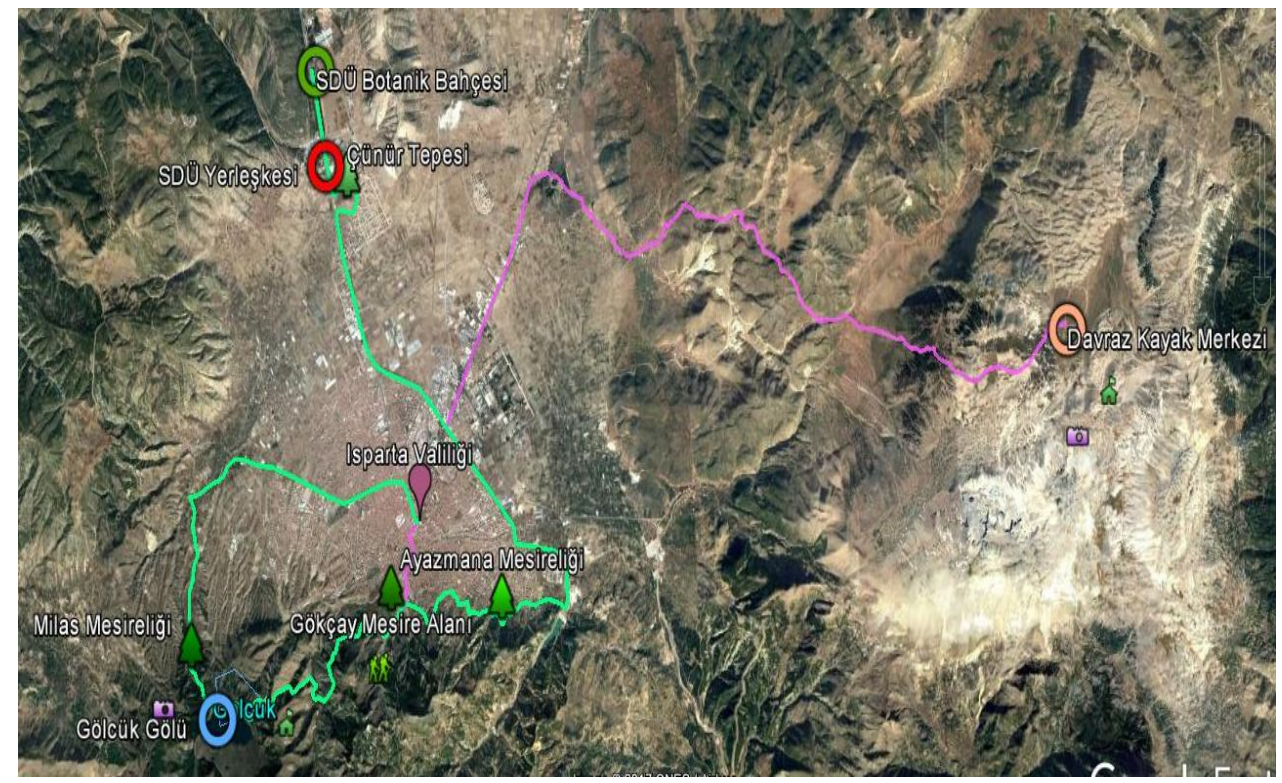

Şekil 8. Isparta Kenti 4. Nolu Ekoturizm Rotası

\section{SONUÇ ve ÖNERILER}

Ekoturizm, bölge ve yörelerin gelişmesinde önemli rol oynayan bir turizm türüdür. Bu bağlamda bu turizm etkinlikleri kent turizminin geliştirilmesinde ekoturizm faaliyetlerinin önem kazanmasına ve yaygınlaşmasına neden olacaktır. Kent ekoturizmi, yerel deneyimlerin güçlenmesi, farklı kültürdeki insan topluluklarının bir araya gelmesi, yöresel değerlerin önem kazanması, yöresel ve bölgesel ekonominin canlanması, insanların yeni yerler keşfetmesi, doğal çevreye sahip çıkma bilincinin kazanılması gibi pek çok sosyal, ekonomik, ekolojik ve çevresel yararlar sağlamaktadır.

Kent turizminin eyleme dönüştürülmesi için özellikle yerel yöneticiler, şehir ve peyzaj plancılarının, doğal ve kültürel çevreye duyarlı, yerel halkın ve turistlerin talep ve tercihlerini dikkate alan bir yaklaşımı benimsemeleri gerekmektedir. Bunun yanı sira kentin mevcut ve potansiyel doğal ve kültürel değerlerin belirlenmesi, bu potansiyel değerler, etkinlikler ve kullanıcılar arasında ilişkilendirilerek analiz edilmesi, her kentin koruma ve kullanma dengesini gözeten sürdürülebilir bir turizm anlayışının benimsenmesi ve doğrultuda kentin ekoturizm eylem planının oluşturulması gerekmektedir.

Isparta kenti ekoturizm amaçlı çeşitli potansiyel kaynaklara sahiptir. Bu kaynakların değerlendirilmesi kapsamında yapılacak her türlü girişim kentin 
gelişiminde büyük katkılar sağlayacaktır. Bu çabalar bir yandan kent insanının farkındalığını ve bilinçlenmesini artırabileceği ve eylemsel olarak daha aktif olmasını sağlayabileceği gibi diğer yandan da daha fazla turist çekebilmek ve kentin tanıtımı için fırsat yaratabilecektir. Bu durum kentin kalkınması ve gelişmesine de katkı sağlayacaktır. Bu doğrultuda yerel yönetimlerin ve ilgili paydaşların ortak hareket ederek sinerji ve işbirliği oluşturmaları gerekmektedir. Isparta'da kent ekoturizminin geliştirilmesinde söylem boyutundan eylem boyutuna geçebilmek için aşağıda belirtilen öneriler dikkate alınmalıdır;

- Isparta kent ekoturizmi için kent içi ve yakın çevresinin mevcut ve potansiyel doğal ve kültürel kaynaklar belirlenmeli ve envanteri çıkarılmalıdır,

- Potansiyel kaynaklar, öngörülen ekoturizm etkinlikleri ile ilişkilendirilerek bu etkinliklerin yapılabileceği rotalar belirlenmelidir,

- Kente özgü ekoturizm eylem planı yapılmalıdır. Eylem planı kapsamında ekoturizm stratejik planlama ilkeleri ve politikaları belirlenmelidir. Eylem planında etkinlik rotalarının mekânsal tasarım uygulama projeleri yapılmalıdır. Mutlaka her bir rotanın taşıma kapasitesi belirlenmelidir,

- Ekoturizm stratejik planlaması ve eylem planlaması ilgili meslek disiplinlerinin ortak çalışması ile gerçekleştirilmelidir,

- Kent ekoturizminin gelişmesi için katma değer yaratacak ürün tasarımları yapılmalı ve bunların üretim ve pazarlamasına yönelik çalışmalar yürütülmelidir,

- Ekoturizm etkinlikleri kentin doğasına ve ekolojik/çevresel yapısına katkı sağlayacak programlar, eğitsel etkinlikler ve organizasyonlar içermelidir,

- Ekoturizm etkinlikleri ve rotalar, yerel halkı ve ziyaretçileri kapsayacak şekilde çok yönlü olarak düşünülmelidir,

- Kent ekoturizmi etkinlikleri için gerek kent insanı gerekse turistler için yazılı ve görsel materyaller hazırlanmalı, ulusal ve uluslararası ölçekte tanıtımı yapilmalıdır,

- Isparta kent merkezinde mevcut Isparta gül tarlalarının korunması ve ekoturizm etkinlikleri kapsamında değerlendirilmesi sağlanmalıdır. Bunun yanısıra tıbbi ve aromatik bitkilerin üretilmesi ve yetiştirilmesi için teşvik edilmeli ve finansal destek sağlanmalıdır,

- Kent içinde veya yakın çevresinde hobi bahçeleri tasarlanmalı ve uygulanmalıdir,

- Yöresel ve organik ürünlerin sergilendiği ve satıldığı organik pazarlar tasarlanmalidir,

- Isparta Çevre Düzeni planında ekoturizm stratejik planlama ilkeleri ve politikalarına yönelik genel çerçeve belirlenmelidir. Kentin imar planlarında ve koruma amaçlı imar planlarında kültürel ve doğal değerleri korumaya yönelik kararlar alınmalıdır,

- Isparta kent merkezinde yapılacak ekoturizm etkinlikleri kapsamında; doğa yürüyüşü, dağ bisikleti, bitki ve yaban hayatı gözlemi, doğa fotoğrafçılığ1, orieentering, bitkilendirme çalışmaları (fidan dikimi ve tohum ekimi), erozyon 
önlemeye yönelik toprak ve su koruma çalışmaları, sokak hayvanları bakımına yönelik çalışmalar, çevre kirliliğine önlemeye yönelik faaliyetler, çöp toplama, gül toplama ve gül bahçeleri bakım çalışmaları, park tesisi veya parklarda yabani ot temizliği gibi etkinlikler öngörülebilir,

- Kent ekoturizminin eyleme dönüştürülmesi ve sürdürülebilir olabilmesi için yönetsel ve kurumsal bir yapının organize edilmesi, yetki ve sorumlulukların belirlenmesi gerekmektedir. Bir organizasyon çatısı altında ilgili tüm paydaşlar işbirliği yapmalı, ortak hareket etmeli ve faaliyetler koordine edilmelidir.

- Kent ekoturizmi kapsamında elde edilecek gelirlerden bir fon oluşturulmalı ve bu fon yine ekoturizm çalışmalarının geliştirilmesi için kaynak olarak kullanılmalıdır.

\section{KAYNAKÇA}

Albayrak, A. (2013). Alternatif Turizm, Detay Yayıncılık, 1. Baskı, Ankara.

Blackstone Corporation. (1996). Developing an urban ecotourism strategy for Metropolitan Toronto: A feasibility assessment for the green tourism partnership. Toronto: Toronto Green Tourism Association.

Blamey, R. K. (1997). Ecotourism: The Search for an Operational Definition, Journal of Sustainable Tourism, 5 (2):109-130.

Dodds, R., Joppe, M. (2001). Kentsel yeşil turizmin teşvik edilmesi: Toronto'nun diğer haritasının geliştirilmesi, Vacation Marketing Dergisi, 7(3).

Gül, A., Özaltın, O. (2007). Ekoturizm ve Isparta 1. Gülçevrem, Isparta İl Çevre ve Orman Müdürlüğü. Yıl 2007/2 Sayı:2, sayfa:22-25. Isparta.

Gül, A., Özaltın, O. (2008). Ekoturizm ve Isparta 2. Gülçevrem, Isparta İl Çevre ve Orman Müdürlüğü. Yıl 2008/1 Sayı:3, sayfa:18-21. Isparta.

Higham, J., \& Luck, M. (2002). Urban ecotourism: a contradiction in terms. Journal of Ecotourism, $1(1), 36-51$.

Lawton, L. J., \& Weaver, D. B. (2001). Modified spaces. In D. B. Weaver (Ed.), The encyclopedia of ecotourism (pp. 73-92). Oxon, UK New York, NY: CABI Pub

McLaren, D. (2003). Rethinking Tourism and Ecotravel, Kumarian Press, Westheartcourt.

Okech RN (2009). Developing urban ecotourism in Kenyan cities: A sustainable approach. Journal of Ecology and Natural Environment, 1(1). Available online at http://www.academicjournals.org/JENE.

Paskaleva, K. S. (2001). Promoting Partnership for Effective Governance of Sustainable Urban Tourism. INTA International Seminar; Tourism in the City Opportunity for Regeneration and Development, Conference Book, Turin: Italy.

Paskaleva-Shapira, K. (2007). New Paradigms in City Tourism Management:Redefining Destination Promotion, Journal of Travel Research, 46:108-114. DOI: $10.1177 / 0047287507302394$

Rahemtulla, Y.G. \& Wellstead, A.M. (2001). Ecotourism: Understanding Competing Expert and Academic Definitions. Infor. Report Nor-X-380 Canada. 
Turizm Bakanlığı 1998. Yatırımlar ve Çevre Raporu, Türkiye Cumhuriyetinin 75. Yılı I. Turizm Şurası, 3. Komisyon Raporu, Ankara.

Urban Ecotourism Declaration (UED) (2006). Retrieved 18.05.06, http://www.planeta.com/ ecotravel/tour/urbandeclaration.html.

Whelan, T. (1991). Nature tourism, managing for the environment, Island Press..

Wood, M.E. (2002). Ecotourism: Principles, Practices \& Policies for Sustainability. (United Nations Environment Programme (UNEP) and The International Ecotourism Society (IES).

Wright, P., Hall, C. M., \& Lew, A. A. (Eds.). (1998). Tools for sustainability analysis in planning and managing tourism and recreation in the destination, sustainable tourism: A geographical perspective. New York: Addison Wesley Longman.

Wu, Y. Y., \& Wang, H. L. (2007). Urban ecotourism, a contradiction International Ecotourism Monthly, 90, 8-9.

Wu, Y.Y., Wang, H.L., Ho Y.F. (2010). Urban ecotourism: Defining and assessing dimensions using fuzzy number construction. Tourism Management 31:739-743. 